\title{
Audit Committee Compliance and Company Performance Nexus: Evidence from ASX Listed Companies
}

\author{
Ismail Gani
}

School of Business and Tourism, Southern Cross University, Gold Coast, Australia

\begin{abstract}
Albert Wijeweera
College of Arts \& Sciences, PI Campus, Khalifa University, Abu Dhabi, UAE

School of Business and Tourism, Southern Cross University, Gold Coast, Australia
\end{abstract}

Ian Eddie

School of Business and Tourism, Southern Cross University, Gold Coast, Australia

Received: May 17, 2017 Accepted: June 27, 2017

doi:10.5296/ber.v7i2.11579 URL: https://doi.org/10.5296/ber.v7i2.11579

\begin{abstract}
This study examines whether the compliance with the audit committee recommendations which the Australian Stock Exchange (ASX) Corporate Governance Council (2003, 2007, 2010,2014 ) put forward as part of its corporate governance reforms has enhanced corporate performance of ASX listed companies. Using company performance variables for 97ASX listed companies in the materials sector, the study estimates six different company performance models under two major categories of accounting performance indicators and investor performance indicators. Result clearly suggest that among corporations that operated within the materials sector and ranked in the top 500 companies listed on the ASX, those that complied with ASX recommendation of audit committee requirements, have achieved a higher corporate performances as measured by return on assets (ROA) and return on equity (ROE) as opposed to those firms that did not comply with the recommendation.
\end{abstract}

Keywords: Company performance, Audit committees, Corporate governance 


\section{Introduction}

The rapid growth of ASX listed companies and their increase in the direct share ownership by the Australian people have impelled the Australian government and market regulators to introduce a series of significant corporate governance reforms since early 2000s. An interesting feature of the reformed Australian regulatory framework is a combination of mandatory obligations and less stringent recommended guidelines. In relation to the audit committee of listed companies, ASX Corporate Governance Council (2003) recommends that the board should establish an audit committee consisting of at least three members with a majority of independent directors. It further specifies that only non-executive directors can be a part of the committee and it should be chaired by an independent chairperson, who is not chairperson of the board. This recommendation is widely known as Recommendation of 4.3 and has been reaffirmed in subsequent corporate governance reforms in 2007 and 2010.

In this paper, we investigate whether the compliance with the audit committee recommendation 4.3 by the ASX Corporate Governance Council has enhanced the corporate performance of some selected ASX listed companies. There is a gap in the literature on the correlation between audit committees and corporate performance from an Australian perspective, as the current literature does not adequately address the research problem. The objective of this study is to address the gap in the literature by examining whether compliance or non-compliance of ASX Recommendations 4.3 as part of Australia's corporate governance reforms, is related to the performance of corporations.

This issue is particularly worthy of investigation because while corporate advocates claim that good corporate governance policies are associated with improvements in performance, opponents argue that over-regulation may distract management and hence lowering the growth of the company performance. We analyze data from 97 ASX listed companies in the materials sector over the period 2007-2009 to investigate possible relationship between compliance with the audit committee requirements and various measures of corporate performance. Since the data sample contains both the time series component and cross sectional component, we use panel data estimation procedure for estimating the relationship. The rest of the paper proceeds as follows.

After the introduction, Section 2 provides background information on corporate governance reforms in general and that are specific to Australia. Section 3 presents a brief literature review on the topic. The data and the methodology are discussed in Section 4 before discussing results in Section 5. The concluding remarks are given in Section 6.

\section{Institutional Framework}

The Australian regulatory framework is a combination of mandatory requirements and less stringent recommended guidelines. The current Australian regulatory structure promotes uniformity of corporate regulation and economies of scale in national law making and enforcement (Redmond 2005, p. 56). The Commonwealth government in consultation with the Australian Securities and Investments Commission (ASIC), ASX, accounting and legal professions together with consultative bodies, have been progressively reforming Australia's 
corporate law (Stretton 2004, p. 28; Tomasic 2001).

The Commonwealth government's corporate and financial sector regulation reforms led to the development of the Corporate Law Economic Reform Program (CLERP, which made significant changes to corporate regulation in areas of 'corporate governance, director's duties, corporate fundraising, takeovers and accounting standards' (Hill \& Koeck 2000, p. 18). The Federal Parliament also passed the Australian Prudential Regulation Authority Act 1998 (Cth) creating a national regulator of prudential institutions known as Australian Prudential Regulation Authority (APRA). The Australian Securities and Investment Commission Act 2001 (Cth) replaced the Australian Securities Commission Act 1989 (Cth) (Lipton \& Herzberg 1999, p. 14). The Commonwealth government also enacted two principal statutes, the Corporations Act 2001 (Cth) and the Australian Securities and Investment Commission Act 2001 (Cth) (ASIC) Ford et al., 2003, p. 51).

The ASX was formed in 1987, incorporating six state based exchanges for equities, derivatives and fixed interest securities (ASX 2006, p. 1). The primary objective of the ASX is to foster an informed, fair and internally competitive financial securities market (Parker \& Porter 2004, p. 340). On 1 August 2002, the ASX established the ASX Corporate Governance Council, a gathering of 21 organisations representing the Australian stakeholder community that aimed at developing a 'corporate governance and disclosure framework' enhancing credibility and transparency through Australian capital markets (KPMG 2003, p. 1).

In March 2003, The ASX Corporate Governance Council (2003) released its 'Principles of Good Corporate Governance and Best Practice Recommendations' which contained ten core recommended principles of best practice guidelines. The 2003 audit committee requirements recommended by the ASX Corporate Governance Council are contained in Table 1:

Table 1. 2003 ASX Recommendations on Audit Committees

\begin{tabular}{|c|c|}
\hline ASX Recommendation & Description of Recommendation \\
\hline $\begin{array}{l}\text { Recommendation } 4.2 \\
\text { (The } 2007 \text { \& } 2010 \text { Versions renamed as Recommendation } 4.1 \text { ) and } \\
\text { (The } 2014 \text { Version grouped Recommendation } 4.2 \text { and } 4.3 \text { by listing } \\
\text { them all under Recommendation 4.1). }\end{array}$ & $\begin{array}{l}\text { The board should establish an audit } \\
\text { committee. }\end{array}$ \\
\hline $\begin{array}{l}\text { Recommendation } 4.3 \\
\text { (The } 2007 \text { \& } 2010 \text { Versions renamed as Recommendation 4.2) and } \\
\text { (The } 2014 \text { Version grouped Recommendation } 4.2 \text { and } 4.3 \text { by listing } \\
\text { them all under Recommendation 4.1). }\end{array}$ & $\begin{array}{l}\text { Structure the audit committee so that it } \\
\text { consists of: } \\
\checkmark \quad \text { only non-executive } \\
\text { directors; and } \\
\checkmark \quad \text { a majority of independent } \\
\text { directors; and } \\
\checkmark \quad \text { an independent } \\
\text { chairperson, who is not } \\
\text { chairperson of the board; and } \\
\checkmark \quad \text { at least three members. }\end{array}$ \\
\hline
\end{tabular}

Source: ASX Corporate Governance Council 2003, pp. 29-30 
In 2007 and further in 2010, the ASX Corporate Governance Council repeated the above recommendations in subsequent versions by renaming Recommendation 4.2 as Recommendation 4.1 and Recommendation 4.3 as Recommendation 4.2 (ASX Corporate Governance Council 2007, 2010). The 2014 version renamed Principle 4 as 'Safeguard Integrity in Corporate Reporting' and simplified the previous requirements by listing them all under Recommendation 4.1 (ASX Corporate Governance Council 2014). ASX Listing Rule 12.7 requires the top 300 corporations listed on the exchange to comply with Recommendation 4.3 (ASX Corporate Governance Council 2003, 2007, 2010, 2014).

The ASX advocates that 'the existence of an independent audit committee is recognised internationally as an important feature of a good corporate governance mechanism' (ASX Corporate Governance Council 2003, p. 30). The ASX acknowledged that the ASX Corporate Governance Council's recommendations cannot be enforced and will not prevent corporate failure or mistake, however, they do provide guidance to reduce the risk of problems and enhance performance and accountability (ASX Corporate Governance Council 2003, p. 3).

\section{Literature Review}

The implementation of corporate governance reforms and the various aspects of these reforms have been rigorously studied by many researchers in order to determine whether they improve the economic performance of corporations (Dey 2008). However, since the Australian corporate governance reforms were introduced, there has been limited research on the correlation between audit committees and corporate performance (Hutchinson,et al., 2008). The research that has been conducted on the correlation between audit committees and corporate performance has largely produced inconsistent results.

Studies conducted by Al-Matari et al. (2012) and Aldamen et al. (2012) reported a positive relationship between audit committees and corporate performance. Whilst these studies provide a positive outcome in agreement with this study, they produced different results depending on performance measures, compliance and structure variables. The results of the UK post-Cadbury Code reforms study conducted by McKnight et al. (2009, p. 37) found that the establishment of audit committees had a positive impact on corporate performance. The results show a positive relationship between the existence of an audit committee and corporate performance rather than the requirements imposed on the structure audit committees.

Hamdan, et al. (2013) in a more recent study that included 106 corporations listed on the Amman Stock Exchange measured the characteristics of audit committee size, financial expertise and independence using three separate measures of; financial performance, operating performance and stock performance. They found a significant positive relationship between audit committee characteristics and financial and stock performance. The present study investigated similar audit committee characteristics and also produced positive results, except in the case of financial expertise.

In an Australian study conducted during adverse economic conditions, Aldamen et al. (2012, p. 971) found that 'smaller audit committees with more experience and financial expertise are 
more likely to be associated with positive firm performance in the market'. However, studies conducted by Bozec (2005), Klein (1998), and Reddy et al. (2011) did not find a positive relationship between audit committees and corporate performance.

Lama (2011) conducted an Australian comparative study of 100 randomly selected non-top 500 ASX listed companies of which 50 firms had an audit committee in compliance with ASX recommendation 4.3 and 50 firms did not have an audit committee. The study utilised the financial data of the 100 firms for the period 1 July 2000 to 1 July 2005 and excluded firms that did not have a 30 June reporting date (Lama 2011). The study used the performance measure of beta and return on assets and applied a means comparison and regression analysis and found that the 'existence of an audit committee does not seem to impact either firm's stock volatility as measured by beta or its operating efficiency as measured by return on assets. The present study can be differentiated from Lama's (2011) study. Lama's (2011) study was conducted on 100 randomly selected non-top 500 ASX listed companies. It was not industry specific and the corporations involved were likely to be from multiple GICS sectors, whereas this study was conducted on corporations that operate within the materials sector ranked in the top 500 companies.

\section{Data and the Methodology}

As stated earlier, this study examines whether compliance of audit committee has enhanced corporate performance in selected ASX listed companies. We analyze data from 97 ASX listed firms for the financial years 30 June 2006, 30 June 2007 and 30 June 2008. The data period is of particular significance because it covers the Global Financial Crisis period where compliance became a major topic of interest. The data includes board characteristics, audit committee characteristics and financial data for corporations which were operating in the materials sector and which were ranked in the top 500 companies by market capitalization. In order to provide consistency, validity, and reliability and decrease the complexity of this study, only corporations operating in the same Global Industry Classification Standard (GICS) sector were included in this study. The 97 companies listed on the ASX operating in the materials sector were identified by the GICS Code. Although the initial data sample consists of data from 97 companies, data from 43 companies were excluded from the final analysis due to missing data or inconsistencies of the data resulting total number of 162 observations (3 years - 54 firms).

One of the critical components of this study is the selection of a performance variable or the dependent variable of the panel regression model. As far as existing studies are concerned, there is no consensus on what is a proper measure of financial performance variable. In general, those measures fall into the two categories: accounting returns and investor returns (Dalton \& Kesner 1985). Following this advice, we opt to use three accounting performance measures and three investor return performance measures in this analysis. This has resulted six different regression models, but under two different categories. The three accounting measure dependent variables that we have used in this study are: Reported Net Profit (RNP), Return on Assets (ROA), and Return on Equity ( ROE). RNP is expressed to the nearest million dollars while ROA and ROE are expressed in terms of percentages. The three investor 
return performance variables are: the positive or negative deviation from the overall Market (M), the Price Earnings Ratio (PER), and the Price Cash Flow Ratio (PCFR). PER is calculated as the current market price divided by the reported earnings per share before non-recurring items while PCFR is calculated as the closing stock price as at the end of the fiscal year divided by the cash flow per share of the latest fiscal year.

Accordingly, we have six different company performance models. Each model contains five identical explanatory variables. Since the main purpose of this study is to investigate whether compliance of the audit committee requirements has enhanced the performance of ASX listed companies, one of the explanatory variables should indicate whether the company acts in accordance with the recommendation. Subsequently, we included a dummy variable (COMPLY) in each model such that corporations that compiled with ASX recommendation were assigned 1 and those that did not comply were assigned 0 . The other four explanatory variables are, the size of the Board (TOTALDIR), Gross Domestic Product of Australia (GDP), All Ordinaries Index (ALLORDS), and the total remuneration paid for each CEO (CEOPAY) which includes salary, bonuses, super, leave entitlement, options, and any other financial entitlements. A brief description of variables that we have included in the estimations are given in Table 2.

Table 2. Variables

\begin{tabular}{|l|l|l|}
\hline Independent Variables & $\begin{array}{l}\text { Corporate Performance } \\
\text { Dependent Variables } \\
\text { (Accounting Measures) }\end{array}$ & $\begin{array}{l}\text { Corporate Performance } \\
\text { Dependent Variables } \\
\text { (Shareholder Measures) }\end{array}$ \\
\hline $\begin{array}{l}\text { Compliance with ASX } \\
\text { Rec. 4.3. (COMPLY) }\end{array}$ & $\begin{array}{l}\text { Reported Net Profit } \\
\text { \$mil - (RNP) }\end{array}$ & + - Market \% - (M) \\
\hline The size of the board (TOTALDIR) & Return on Assets \% - (ROA) & Price / Earnings Ratio - (PER) \\
\hline Gross Domestic Product (GDP) & Return on Equity \% - (ROE) & Price/Cash Flow Ratio- (PCFR) \\
\hline All Ordinaries Index (ALLORDS) & & \\
\hline CEO Remuneration (CEOPAY) & & \\
\hline
\end{tabular}

As the data sample contains the combination of both time-series data and cross-sectional data we have used panel regression approach to estimate the models. We have considered all three main panel estimation methods ( pooled, fixed effects and random effects) in this study. The pooled ordinary least squared model was not considered appropriate for this study as it is based on an assumption that the regression coefficients for all corporations studied are the same and that there are no differences between the corporations (Gujarati \& Porter 2009). The fixed effects model, in contrast to the pooled model, allows for heterogeneity between the entities studied but does not take into account time-invariant characteristics (Gujarati \& Porter 2009). Accordingly, the random effect model is used to estimate six different company performance equations. The general specification of the performance equation is given below.

$$
Y_{i t}=\alpha+\beta_{1} X_{1 i t}+\beta_{2} X_{2 i t}+\beta_{3} X_{3 i t}+\beta_{4} D_{1 i t}+\beta_{5} D_{2 i t}+U_{i t}
$$

Where; $\mathrm{Y}$ is the dependent variable ( RNP, ROA, ROE, M, PER, PCFR), $i$ is the subject 
CODE, $t$ is the YEAR, $\beta$ is the estimated coefficient, $X_{1}$ is the GDP, $X_{2}$ is the ALLORDS, $X_{3}$ is the CEOPAY, $\mathrm{D}_{1}$ is COMPLY, $\mathrm{D}_{2}$ is the TOTALDIR and $\mathrm{U}$ represents the error term.

We now proceed to discussion of results. As explained earlier, we estimate six different models, but under two main categories of accounting performance measured and investor performance measures. Table 3 presents results based on accounting performance measures while Table 4 shows results based on investor return performance measures.

\section{Discussion of Results}

The objective of this study was to determine whether compliance or non-compliance with ASX Recommendation 4.3 as part of Australia's corporate governance reforms is related to the performance of corporations as measured by accounting methods and shareholder value methods. Results shown in Table 3 and 4 suggest that no reliable statistical inferences can be made from models based on RNP, M, PER and PCFR because overall fitness of the models seems very weak judging by low adjusted R-squared values and F-statistics values.

Table 3. Accounting Return Performance Based Results

\begin{tabular}{|l|c|c|c|c|c|c|}
\hline & \multicolumn{2}{|c|}{ Reported Net Profit $-(\mathrm{RNP})$} & \multicolumn{2}{l|}{ Return on Assets - (ROA) } & \multicolumn{2}{c|}{ Return on Equity - (ROE) } \\
\hline Variable & Coefficient & P-value & Coefficient & P-value & Coefficient & P-value \\
\hline C & -146.445 & 0.6960 & -21.22673 & 0.1007 & -5.911492 & 0.8114 \\
\hline COMPLY & 680.117 & 0.1418 & 12.45017 & 0.0097 & 21.88637 & 0.0024 \\
\hline TOTALDIR & -36.9368 & 0.1177 & 3.396400 & 0.0046 & 4.391145 & 0.0249 \\
\hline GDP & 0.18831 & 0.0745 & 0.017128 & 0.0356 & 0.016732 & 0.2869 \\
\hline ALLORDS & 0.02232 & 0.3135 & -0.001891 & 0.3051 & -0.005883 & 0.1047 \\
\hline CEOPAY & $1.40 \mathrm{E}-05$ & 0.2651 & $-5.90 \mathrm{E}-06$ & 0.0000 & $-5.84 \mathrm{E}-06$ & 0.0005 \\
\hline Adjusted $R^{2}$ & 0.01257 & 165.2829 & 0.245627 & 14.90733 & 0.158242 & 27.28845 \\
\hline$F$-statistic & 1.410189 & 1.196700 & 11.48445 & 2.116773 & 7.053291 & 2.145126 \\
\hline
\end{tabular}

Table 4. Investor Return Performance Based Results

\begin{tabular}{|l|c|c|c|c|c|c|}
\hline & \multicolumn{2}{|l|}{ +/- Market $-(\mathrm{M})$} & \multicolumn{2}{c|}{ Price / Earnings Ratio - (PER) } & \multicolumn{2}{c|}{ Price / Cash Flow Ratio - (PCFR) } \\
\hline \multicolumn{1}{|c|}{ Variable } & Coefficient & P-value & Coefficient & P-value & Coefficient & P-value \\
\hline C & 220.986 & 0.1635 & -72.26749 & 0.5897 & -161.3187 & 0.2497 \\
\hline COMPLY & -29.4791 & 0.3364 & 33.98562 & 0.2918 & 59.01590 & 0.0306 \\
\hline TOTALDIR & -5.35110 & 0.5664 & 3.620506 & 0.6966 & 6.461511 & 0.4340 \\
\hline GDP & -0.21247 & 0.0366 & 0.059041 & 0.4882 & 0.147935 & 0.0989 \\
\hline ALLORDS & 0.01945 & 0.4079 & -0.012041 & 0.5415 & -0.012457 & 0.5489 \\
\hline CEOPAY & $-8.91 \mathrm{E}-0$ & 0.3167 & $9.11 \mathrm{E}-06$ & 0.2778 & $6.15 \mathrm{E}-07$ & 0.9377 \\
\hline Adjusted $R^{2}$ & 0.04575 & 166.1617 & 0.013744 & 135.4276 & 0.057302 & 149.8944 \\
\hline$F$-statistic & 2.543907 & 2.072924 & 1.448722 & 2.108932 & 2.957295 & 1.661541 \\
\hline
\end{tabular}

The results based on ROA and ROE show that among corporations that operated within the materials sector and ranked in the top 500 companies (by market capitalisation) listed on the ASX, those that complied with ASX Recommendation 4.3, have achieved higher corporate performances as measured by return on assets and return on equity. The results produced 
positive coefficients for both dummy variables that represent for corporate governance reforms.

As far as ROA results are concerned, the coefficient of COMPLY is 12.45017 suggesting that the return on assets ratios of those corporations that complied with ASX Recommendation 4.3 were $12.45 \%$ higher than the return on assets ratios of those organisations that did not comply. The return on assets ratio is a profitability measure of a corporation's 'ability to convert sales revenue into profit, and its ability to generate income from its asset investments' (Birt et al. 2008, p. 289). A higher return on assets ratio reflects more effective trading through profitability and asset efficiency (Birt et al. 2008, p. 290; Cooper et al. 1997, p. 230).

Similarly, results based on dependent variable ROE suggest that corporations that complied with ASX Recommendation 4.3 also reported improved returns. The return on equity ratio is a profitability measure for the profit made by the corporation on its total equity (Birt et al. 2008 , p. 289). The return on equity ratio indicates the return on the owner's investment and reflects the direction of corporation's profitability, asset efficiency and capital structure (Bazley et al. 2010, p. 428; Birt et al. 2008, p. 289; Cooper et al. 1997, p. 231). The results have produced a value of 21.88637 for the COMPLY variable, thereby suggesting that the return on equity ratios of those corporations that complied with ASX Recommendation 4.3 were $21.89 \%$ higher than those organisations that did not comply.

The above results suggest that our findings are in line with some studies (Al-Matari et al. 2012; Aldamen et al. 2012; Hamdan, Sarea \& Reyad 2013; McKnight et al. 2009) that found the establishment of audit committees had a positive impact on corporate performance. However, our results are in contrast with studies conducted by Bozec (2005), Weir and Laing (2001), Dulewicz and Herbert (2004), Reddy et al. (2011) and Lama (2011), who did not find a positive relationship between audit committees and corporate performance. Table 5 presents a summary of the conclusions drawn by various studies conducted on the relationship between audit committees and corporate performance.

Table 5. Summary of Studies on the relationship between audit committees and corporate performance

\begin{tabular}{|l|l|}
\hline Study & Result \\
\hline McKnight et al. 2009 & Positive \\
\hline Bozec 2005 & Nil \\
\hline Klein 1998 & Nil \\
\hline Weir and Laing 2001 & Nil \\
\hline Dulewicz and Herbert 2004 & Nil \\
\hline Reddy et al. 2011 & Nil \\
\hline Lama 2011 & Nil \\
\hline Al-Matari et al. 2012 & Mixed \\
\hline Hamdan et al. 2013 & Positive \\
\hline Aldaman et al. 2012 & Mixed \\
\hline
\end{tabular}




\section{Conclusion}

We have used a data set that comprises of 97 publicly listed materials sector companies for three-year period to determine whether compliance or non-compliance with Australian Stock Exchange Recommendation 4.3 as part of Australia's corporate governance reforms is related to the performance of corporations as measured by accounting performance and shareholder value methods.

The results from this research indicate that among corporations that operated within the materials sector and ranked in the top 500 companies (by market capitalisation) listed on the ASX, those that complied with Australian Stock Exchange Recommendation 4.3, achieved a higher corporate performance as measured by ROA and ROE compared to those who did not comply with the recommendation.

The implication arising from this research are significant for corporate regulators and stock exchange because the evidence indicates structuring an audit committee complying with the Australian Stock Exchange requirements will enhance shareholder returns and also result in overall greater financial performance for companies.

There is a need to extend this research to cover additional industry sectors and to determine whether these results can also be replicated in other stock markets. Additional evidence from diverse industry sectors and under different market conditions will strengthen the case for establishing board audit committees comprising independent board members.

\section{Reference}

Al-Matari, Y. A., Al-Swidi, A. K., Fadzil, F. H. B., \& Al-Matari, E. M. (2012). Board of Directors, Audit Committee Characteristics and Performance of Saudi Arabia Listed Companies, International Review of Management and Marketing, 2(4), 241-251.

Aldamen, H., Duncan, K., Kelly, S., McNamara, R., \& Nagel, S. (2012). Audit Committee Characteristics and Firm Performance during the Global Financial Crisis, Accounting and Finance, 52(4), 971-1000. https://doi.org/10.1111/j.1467-629X.2011.00447.x

ASX (2006). ASX Overview \& Structure, viewed 11 February 2006, <http://www.asx.com.au/about/asx/asx_overview.htm>.

ASX (2013), Australian Share Ownership Study, viewed 15 August 2014, <http://www.asx.com.au/documents/resources/asx-sos-2012.pdf>.

ASX Corporate Governance Council 2003, 2007, 2010, and 2014, Corporate Governance Principles and Recommendations, 3rd Edition, ASX, viewed 15 August 2014, $<$ http://www.asx.com.au/documents/asx-compliance/cgc-principles-and-recommendations-3r d-edn.pdf $>$.

Bazley, M., Hancock, P., \& Porter, S. (2010). Financial Accounting; A Conceptual Approach, 1st edn, Cengage Learning Australia Pty Limited, South Melbourne.

Birt, J., Chalmers, K., Beal, D., Brooks, A., Bryne, S., \& Oliver, J. (2008). Accounting: 


\section{Macrothink}

Business and Economic Research ISSN 2162-4860 2017, Vol. 7, No. 2

Business Reporting for Decision Making, 2nd edn, John Wiley \& Sons Australia Ltd, Milton QLD.

Bosch, H. 1995, Corporate Practices and Conduct, 3rd edn, Pitman Publishing, South Melbourne.

Bozec, R. (2005). Board of Directors, Market Discipline and Firm Performance, Journal of Business Finance \& Accounting, 32(9) \& (10), 1921-1960.

Cooper, B. J., Leung, P., Mathews, C., \& Carlson, P. (1997), Accounting \& Finance for Managers, Jacaranda Wiley Ltd, Milton, QLD.

Dey, A. (2008). Corporate Governance and Agency Conflicts, Journal of Accounting Research, 46(5), 1143-1181. https://doi.org/10.1111/j.1475-679x.2008.00301.x

Dulewicz, V., \& Herbert, P. (2004). Does the Composition and Practice of Boards of Directors Bear any Relationship to the Performance of thier Companies?, Corporate Governance, 12(3), 263-280. https://doi.org/10.1111/j.1467-8683.2004.00368.x

Ford, H. A. J., Austin, R. P., \& Ramsey, I. M. (2003). Ford's Principles of Corporation Law, 11th edn, Lexis Nexis Butterworths, Sydney.

Gujarati, D. N., \& Porter, D. C. (2009). Basic Econometrics, 5th edn, McGraw-Hill Irwin, New York.

Hamdan, A. M., Sarea, A. M., \& Reyad, S. M. R. (2013). The Impact of Audit Committee Characteristics on the Performance: Evidence from Jordan, International Management Review, 9(1), 32-87.

Hill, J., \& Koeck, W. J. (2000). CLERP: What it Means to Corporate Australia, Australian Company Secretary, 52(1), 18-28.

Hutchinson, M. R., Percy, M., \& Erkurtoglu, L. (2008). An Investigation of the Association between Corporate Governance Earnings Management and the Effects of Governance Reforms, Accounting Research Journal, 21(3), 239-262.

https://doi.org/10.1108/10309610810922495

Klein, A. (1998). Firm Performance and Board Committee Structure, The Journal of Law \& Economics, 41(1), 275-303. https://doi.org/10.1086/467391

KPMG (2003). ASX Principles of Good Corporate Governance and Best Practice Recommendations, viewed 30 May 2005,

<http://www.kpmg.com.au/aci/docs/asx_03FR-06.pdf>.

Lama, T. (2011). Mandatory Audit Committees in Australia: Are there Economic Justifications, e-Journal of Social \& Behavioural Research in Business, 2(1), 8-23.

Lipton, P., \& Herzberg, A. (1999). Understanding Company Law, 8th edn, LBC Information Services, Sydney.

McKnight, P. J., Milonas, N. T., Travlos, N. G., \& Weir, C. (2009). The Cadbury Code 


\section{Macrothink}

Business and Economic Research

ISSN 2162-4860 2017, Vol. 7, No. 2

Reforms and Corporate Governance, The IUP Journal of Corporate Governance, 8(1), 22-42.

Parker, C., \& Porter, B. (2004). Australian GAAP (Generally Accepted Accounting Principles) as at 1 January 2004, Parker Publishing, Melbourne.

Reddy, K., Locke, S., \& Scrimgeour, F. (2011). Improving Performance in New Zealand's Public Corporations: The Effect of Governance Practices, Governance: An International Journal of Policy, Administration, and Institutions, 24(3), 517-556.

https://doi.org/10.1111/j.1468-0491.2011.01537.x

Redmond, P. (2005). Companies and Securities Law Commentary and Materials, 4th edn, Lawbook Co, Pyrmont.

Weir, C., \& Laing, D. (2001). Governance Structures, Director Independence and Corporate Performance in the UK, European Business Review, 13(2), 86-94.

https://doi.org/10.1108/09555340110385254

\section{Copyright Disclaimer}

Copyright for this article is retained by the author(s), with first publication rights granted to the journal.

This is an open-access article distributed under the terms and conditions of the Creative Commons Attribution license (http://creativecommons.org/licenses/by/3.0/). 